Іванюта Ольга

кандидат психологічних наук, доцент, доцент кафедри психології Міжнародного економіко-гуманітарного університету імені академіка Степана Дем'янчука https://orcid.org/0000-0002-3316-9879

Яницька Олена кандидат педагогічних наук, доцент, професор кафедри початкової та дошкільної освіти Міжнародного економіко-гуманітарного університету імені академіка Степана Дем'янчука https://orcid.org/0000-0003-4965-1720

DOI https://doi.org/10.35619/praprv.v1i16.213

\title{
ПСИХОЛОГО-ПЕДАГОГІЧНІ ОСНОВИ ДОСЛІДЖЕННЯ ЦІЛЕПОКЛАДАННЯ У СТУДЕНТСЬКОї МОЛОДІ
}

\begin{abstract}
Анотація. У статті здійснена спроба теоретичного узагальнення наукових доробок актуальної проблеми розвитку иілепокладання у юнаџькому віці. Висвітлено проблему поетапного формування иілепокладання : формування иілі та ї̈ досягнення у студентів. Проаналізовано значимість, зміст мотивів, структуру потреб, які визнають особливості цілепокладання. Обгрунтовано проблему : цілепокладання створює певне направлення $у$ житті, однак, більшість студентів мають невисокі показники за критерієм «цілі в житті». У статті висвітлено функиіонально-значимі компоненти, а саме: мотиви, цілі, діі; проаналізовано дослідження щзодо мотиваџіï студентів до цілепокладання, в якій переважають егоїстичні мотиви, а сочіальні, пізнавальні дослідницькі - $\epsilon$ другорядними , а також - дослідження гендерних особливостей иілепокладання у студентської молоді.

У статті акцентовано увагу на тому, що механізм иілепокладання не обмежується лише мотивами. Він включає сферу потреб, на основі яких і виникають иілі. Описано структуру потреб: їх стан в даний момент, бажаний стан, переживання відмінності між ними та намагання досягти бажаного. Таким чином, иіль зберігає всі компоненти потреби. Доведено, що дослідження ціле покладання - це аналіз мети в потребувально-мотиваційній сфері. На основі аналізу першоджерел показано, щэо цілі разом з мотивами надають діяльності особистісний характер, тому важливим є складання плану реалізації иілі в прочесі діяльності. Проаналізовано роль здібностей у цілепокладанні. Зазначається, щзо саме здібності ( $y$ першу чергу до навчання та праці) сприяють успішному виконанню запланованої діяльності. На основі здійсненого аналізу досліджень обтрунтовано положення про те, щчо ичілепокладання - це не лише діяльність, але й - здібності, які можна розвинути за певних умов (Попов, Дмитрієва). Здійснений аналіз психолого-педагогічних аспектів дослідження иілепокладання може бути основою добору методик вивчення цілепокладання у здобувачів вищьої освіти.
\end{abstract}

Ключові слова: цілепокладання, мотиви, потреби, діяльність, здібності.

Постановка проблеми. Швидкі зміни соціальної ситуації в усіх сферах суспільного життя пов'язані із необхідністю управління власними діями та проявами активності в цілепокладанні. Сучасна людина постає перед необхідністю вибору цілей, розв'язання особистісних завдань, які пов'язані з осмисленням життєвого шляху, так як важливою умовою самореалізації $\epsilon$ цілепокладання. Таким чином, сьогодення вимагає постійної роботи молодого покоління над собою, життєвої та професійної самореалізації, яка передбачає результати вибору студентами особистісної позиції, цілей та засобів їх досягнення. 
Життєві орієнтири сучасної молоді не постійні. Це пов’язано 3 нестабільністю у політичній і економічній сферах нашого суспільства. За таких умов прийняття стратегічних рішень молоддю є важким та нестабільним. Наявність цих тенденцій обумовлює доцільність підготовки студентської молоді до планування життєвих цілей. Успішність цього процесу залежить від повноти урахування психолого-педагогічних основ цілепокладання.

Аналіз останніх досліджень 3 проблеми. Процес цілепокладання здобувачів вищої освіти належить до числа найменш досліджених психологічних проблем. У психології існують лише окремі роботи присвячені аналізу процесу постановки суб'єктом цілей (Петровський). У дослідженнях Шрайдера вивчаються потреби, як психологічний фактор розвитку цілепокладання особистості. Аналіз здібностей до цілепокладання у студентів та аспірантів ми знаходимо у роботі Дмитрієвої. В дослідженні Ульянова цілепокладання студентів визначається, як одна із складових готовності майбутнього фахівця до управлінської діяльності. У роботах Гінзбурга відзначається, що ціле покладання, окрім процесу постановки суб'єктом цілі, включає нові цільові перспективи у індивіда (часова перспектива в структурі цілепокладання). Петровський акцентує увагу на нових ресурсах можливих взаємодій суб'єкта, що є перспективою розвитку його діяльності та розвитку його самості.

Мета статті спрямована на розкриття теоретичних підходів до дослідження цілепокладання та вивчення концептуальних підходів щодо визначення сутності, компонентів, особливостей цілепокладання студентів.

Виклад основного матеріалу дослідження. Більшість дослідників розглядають цілепокладання, як інтелектуальну-діяльнісну характеристику особистості, яка проявляється у створенні моделі бажаного результату, подальшому прагненні та праці, спрямованої на його досягнення. Однак, у дослідженнях існує велика відстань між філософськометодологічним трактуванням цілепокладання та чітким визначенням місця цього феномену у складі цілісного інтелектуально-діяльнісного акту суб'єкта. Мета надає життю людини змісту, задає певний напрямок руху, забезпечує можливості особистісної і професійної самореалізації суб'єкта. Як засвідчують дослідження Попова \& Дмитрієвої (2009), більшість здобувачів вищої освіти мають невисокі показники за критерієм «цілепокладання». Наявність цих тенденцій і обумовило наше звернення до цієї проблематики.

У психології мислення проблемі цілепокладання присвячено ряд досліджень. Психологічна модель цілепокладання передбачає два етапи: перший - формування цілі; другий - iї досягнення. Саме тому у психологічну модель включаються особистісні фактори (Головаха, Кроник), які забезпечують функціонування мети діяльності суб'єкта, а також фактори мотиваційні, які спрямовані на досягнення мети (Березанська). Цей процес передбачає отримання змісту та формування особистісного ставлення до цього нього. Особистісні відносини визначають ступінь присвоєння цілі та впливають на її ефективність.

Таким чином, ставлення до цілі проявляється в оціночній активності суб'єкта. Саме тому психологічна модель включає етап додіяльносної (апріорної) оцінки цілі. При цьому оцінюється широке коло умов прийняття цілі : ставлення до наявної мотивації, до установок та цінностей особистості. Апріорне оцінювання носить різний характер та залежить від психологічного захисту критичності, тощо - і є фактором суб'єктивації цілі. За цих умов вимоги перетворюються у реальну ціль індивіда і тому саме стають важливим компонентом структури цілепокладання мотиваційного аспекту. У дослідженні Тєлєгіної доведено залежність вибору цілі від мотиву та рівня домагання, який складається на цій основі. Мотив та ціль визначають вектор діяльності цілепокладання. Цілепокладання, як предмет психологічного аналізу, вивчається у зв'язку із дослідженням його мотиваційних основ та регуляції (Леван, Мартин), інтелектуальної активності (Пушкін), особистісних характеристик суб'єкта (Березанська, Петровський). Для психолого-педагогічного аналізу важливим $\epsilon$ визнання того, що постановка цілей складає сутність процесу цілепокладання.

Варто відзначити, що найбільше визнання отримала концепція Лєонтьєва, який виділив функціонально-значимі компоненти активності: мотиви, цілі, дії, операції. Відповідно до концепції Лєонтьєва первинним фактором мотиваційної сфери особистості є потреби (2004). 
При цьому існує значна відмінність між мотивами та цілями діяльності. Як зазначає психолог, мотив це те, заради чого діяльність здійснюється, мета - іï об’єкт. Перетворення цілі у мотив, свідчить про недопустимість їх протиставлення.

У дослідженні Севостьянова (2018) було виявлено, що вузьких соціальних мотивів (сімейне благополуччя, особистісний комфорт) у цілепокладанні студентів значно більше, ніж соціальних, дослідницьких та пізнавальних. Тобто спостерігається інверсія: переважають егоїстичні мотиви. Автор визначив гендерні особливості цілепокладання. У студенток цілепокладання у більшості пов'язане 3 народженням дітей, придбанням нерухомості; юнаки більшу увагу надають кар'єрному росту, високому заробітку.

Аналіз інверсійних відносин у ієрархічних системах показує, що цілі і мотиви утворюють ієрархічні системи, у яких незначні елементи, з певних обставин, починають набувати головного значення. Це може приводити до соціальних протиріч. У дослідженнях Помиткіної (2019) аналізується постановка та реалізація життєвих цілей здобувачів вищої освіти у найважливіших сферах життя: професійному самовизначенні, виборі шлюбного партнера, визначенні власної життєвої позиції. Дослідником зроблено важливий висновок щодо необхідності підготовки студентської молоді до постановки та реалізації життєвих цілей, що може досягатися шляхом впровадження у практику ЗВО заходів, спрямованих на прийняття студентами стратегічних життєвих рішень.

Проблема постановки і досягнення цілей висвітлена у працях Беха (1996), Помиткіної (2019), Долгих (2006), Карпенко (2009). У дослідженнях доведено, що стратегія постановки цілей започатковується у підлітковому та юнацькому віці, що мотивує молодь на досягнення та готує іï до прийняття відповідальних життєвих рішень. Дія - (важливий компонент діяльності) це процес, який підпорядкований усвідомленій меті. Завдяки діям, які визначаються стратегічними та тактичними цілями і відбувається здійснення діяльності. Роль загальної цілі виконує усвідомлений мотив. Леонтьєв відзначає, що цілі виникають у об'єктивних обставинах (2004). Їх усвідомлення - це не автоматичний, а відносно тривалий процес їх предметного поновлення. Дія досягається різними способами. Способи реалізації діяльності Леонтьєв називає операціями. Діяльність може визначити мотив і тоді вже перетворюється в дію, і навпаки -дія може стати особливою діяльністю або операцією, яка може реалізовувати різні дії.

У процесі діяльності значимість мотивацій змінюється під впливом успіхів та невдач. Від мотивів залежить характер перетворень. Як відмічає Тихоміров, опис механізмів цілепокладання не обмежується лише мотиваційною сферою. Він включає також потребнісну. Таким чином, класифікація потреб може бути використана як критерій класифікації цілей, які виникають на основі цих потреб.

У дослідженнях Моткова виділяється чотири основних компоненти у структурі потреб: наявний стан, бажаний стан, переживання невизначеності між ними, переживання намагань перевести наявне в бажане. Ціль зберігає всі чотири компоненти потреби. Тому в дослідженнях розвитку цілепокладання у період юності вчені традиційно розглядають мету у потребувально-мотиваційній структурі у співвідношенні з дією. Таким чином, цілі, разом 3 мотивами, виступають як визначальним, так і регулюючим аспектом діяльності, тобто надають їй особистісного характеру. Постановка цілі передбачає пізнання обставин діяльності та визначення засобів іiі досягнення. Це, у свою чергу, відображається в плануванні діяльності та прийнятті рішення. Тобто, після того, як поставлена ціль та складено план іiі реалізації, починається діяльність яка складається із дій та включає операції.

Досягнення поставленої цілі - $є$ критерієм ефективності діяльності. Саме тому цілепокладання визначає формування готовності, яку необхідно враховувати при професійній підготовці студентів (Ульянов). Автор пропонує для ефективної підготовки студентів вищих навчальних закладів до професійної «управлінської» діяльності включити в навчальні плани додаткові заняття (семінари, тренінги, майстер-класи) з використанням технологій, які сприяють розвитку навичок цілепокладання.

У дослідженнях Попова відзначається роль здібностей до цілепокладання. Як зазначає автор, саме здібності сприяють реалізації цілей. На думку Рубінштейна, $є$ складною 
синтетичною особливістю особистості, яка визначає ï придатність до діяльності. За Тепловим, їм притаманні три ознаки : приналежність до індивідуально-психологічних якостей; вплив на якість та успішність виконання діяльності; складністю своєї структури, яка не зводиться лише до знань та умінь у людини. Відзначаючи у психології здібностей роль задатків, Нуркова і Березанська підкреслюють, що один і той самий задаток, у залежності від соціальних та індивідуальних умов розвитку дитини, може проявлятися в різних здібностях.

Аналіз досліджень щодо ролі здібностей у цілепокладанні дає підгрунтя розглядати останнє не лише як процес чи діяльність, а й як здібність, яка розвивається за певних умов. Підтвердження цьому ми знаходимо у роботі Попова \& Дмітрієвої (2009). У формуванні цілей важливим $€$ їх структурування за значимістю, часовою перспективою та сферами життя. Цільова структура відображає уявлення шляху, який веде до цілі. Дослідники також відзначають наявність у студентів цілей, які не мають часових меж, але які сприяють поступовому розкриттю духовного потенціалу.

На основі вище проаналізованого очевидно, що для вивчення глибини міркувань щодо майбутнього доцільно використовувати методику, спрямовану на вивчення протяжності та конкретності планів. 3 метою дослідження структурованості завтрашнього дня доцільно використовувати методику виявлення ставлення до планування власного життя (Гінзбург). Важливим моментом в цілепокладанні є дослідження домінантних орієнтацій. 3 цією метою доцільно використовувати Сомоактуалізаційний тест (САТ) у модифікації Загіка \& Гозмана. Він дозволить дослідити рівень самоактуалізації особистості. Студентам можна пропонувати опитувальник, який складається зі 108 суджень САТ і має дві базові шкали: шкала орієнтації в часі та шкалу підтримки. Перша визначає зорієнтованість людина на сьогодення. Друга наявність у людини особистісної мети, чутливість до вплив навколишнього середовища. Самоактуалізована особистість незалежна у поглядах від впливів оточуючих та живе i реалізує себе у сьогоденні. При діагностиці цілепокладання доцільними будуть і методики визначення рівня мотивації досягнень.

Висновки та перспектива подальших розвідок. Здійснений аналіз психологічних аспектів цілепокладання переконливо доводить, що його зміст включає постановку суб'єктом цілей (усвідомлення орієнтирів дій) нової цільової перспективи у індивіда, що становить перспективу розвитку його діяльності і розвитку його як особистості. Тому під час дослідження важливо розглядати часову перспективу в структурі цілепокладання.

Співвідношення цілепокладання 3 мотиваційною-потребнісною сферою $\epsilon$ визначальним для розуміння цілепокладання. Механізм цілепокладання не обмежується мотиваційною сферою, він включає ще й потребувальну. Це необхідно враховувати під час класифікації цілей, які виникають на основі цих потреб. Визначальним у розвитку ціле покладання є підлітковий та юнацький вік. Тому важливо, саме у цьому віці проводити заходи, спрямовані на прийняття юнацтвом стратегічних рішень. Після того, як студент постановив ціль та склав план іiі реалізації - починається діяльність, яка складається 3 дій та операції. У більшості досліджень визначено зміст цілепокладання, який включає постановку суб'єктом цілей (усвідомлених орієнтирів дій), нової цільової перспективи індивіда, що визначає стратегію розвитку його діяльності та особистості. Реалізації цілей сприяють здібності, які визначають психологічну готовність здобувачів вищої освіти до діяльності, насамперед, до навчання та праці. Саме на цих положеннях і має будуватися добір методик вивчення особливостей цілепокладання молоді.

Цілепокладання - творчий процес, тому важливою $є$ творча мисленнєва діяльність суб'єкта. Як зазначає Веракса, в якості форми творчого мислення виступає діалектичне мислення. Саме на цих положеннях і може будуватися добір методики дослідження особливостей цілепокладання у юнацтва: дослідження глибини та структурованості майбутнього у часі, а також виявлення рівня мотивації досягнень. Перспективним напрямком дослідження $\epsilon$ використання обгрунтованих дослідницьких методів, спрямованих на виявлення особливостей цілепокладаючої активності у студентів. 


\section{СПИСОК ПОСИЛАНЬ}

Попов, Л. М., \& Дмитриева, И. А. (2009). Экспериментальное исследование развития способности студентов к целеполаганию. Ученые записки Казанского университета. Гуманитарные науки, 151 (5-1), 266-273. Взято с https://cyberleninka.ru/article/n/eksperimentalnoe-issledovanie-razvitiya-sposobnostistudentov-k-tselepolaganiyu.

Леонтьев, А. Н. (2004). Деятельность, сознание, личность. Избраннье психологические произведения. Москва: Смысл; Академия.

Севостьянов, Д. А. (2018). Социальные инверсии и образование. Высшее образование в России, 12, 39-49. Взято с $\mathrm{https} / / /$ cyberleninka.ru/article/n/sotsialnye-inversii-iobrazovanie.

Помиткіна, Л. (2019). Цілепокладання як основа прийняття студентами стратегічних життєвих рішень. Проблеми сучасної психологї, 20, 531-539. Взято 3 https://doi.org/10.32626/2227-6246.2013-20.\%p.

Бех, І. Д., \& Павелків, Р. В. (1996). Ціннісна система як критерій особистісного виміру. Украӥнська психологія: сучасний потенціал: матеріали Четвертих Костюківських читань, 1, 68-76.

Долгих, Л. М. (2006). Гендерні особливості кар'єрних стратегій студентської молоді. Проблеми загальної та педагогічної психології, 8 (7), 169-175.

Карпенко, 3. С. (2009). Аксіологічна психологія особистості. Івано-Франківськ: Лілея-НВ.

Рыбалка, В. В. (2011). Определение понятий одаренности, таланта, гениальности личности: классические и современные методологические подходы. Одаренный ребенок, 2, 1638 .

\section{REFERENCES}

Popov, L. M., \& Dmitriyeva. I. A. (2009). Eksperimentalnoye issledovaniye razvitiya sposobnosti studentov $\mathrm{k}$ tselepolaganiyu [Experimental study of the development of students' ability of goal-setting]. Uchenyye zapiski Kazanskogo universiteta. Seriya "Gumanitarnyye nauki", 151 (5-1), 266-273. Vzyato z https://cyberleninka.ru/article/n/eksperimentalnoeissledovanie-razvitiya-sposobnosti-studentov-k-tselepolaganiyu. [in Russian].

Leontyev, A. N. (1983). Deyatelnost. soznaniye. lichnost. Izbrannyye psikhologicheskiye proizvedeniya [Activity. consciousness. personality. Selected psychological works]. Moscow: Meaning; Academy. [in Russian].

Sevostianov, D. A. (2018). Sotsialnyye inversii i obrazovaniye [Social inversions and education] Vyssheye obrazovaniye $v \quad$ Rossii, 12, 39-49. Vzyato z https://cyberleninka.ru/article/n/sotsialnye-inversii-i-obrazovanie. [in Russian].

Pomytkina, L. (2019). Tsilepokladannia yak osnova pryiniattia studentamy stratehichnykh zhyttievykh rishen [Goal setting as a basis for students to make strategic life decisions.]. Problemy suchasnoi psykholohi, 20, 531-539. Vzyato z https://doi.org/10.32626/2227-6246.2013-20.\%p. [in Ukrainian].

Bekh, I. D., \& Pavelkiv R. V. (1996). Tsinnisna systema yak kryterii osobystisnoho vymiru [Value system as a criterion of personal dimension]. Ukrainska psykholohiia:suchasnyi potentsial: materialy Chetvertykh Kostiukivskykh chytan, 1, 68-76. [in Ukrainian].

Dolhykh, L. M. (2006). Henderni osoblyvosti kariernykh stratehii studentskoi molodi [Gender features of career strategies of student youth]. Problemy zahalnoi ta pedahohichnoi psykholohii, 8 (7), 169-175. [in Ukrainian].

Karpenko, Z. S. (2009). Aksiolohichna psykholohiia osobystosti [Axiological psychology of personality]. Ivano-Frankivsk: Lileia-NV. [in Ukrainian].

Rybalka, V. V. (2011). Opredeleniye ponyatiy odarennosti, talanta, genialnosti lichnosti: klassicheskiye i sovremennyye metodologicheskiye podkhody [Definition of the concepts of giftedness, talent, genius of personality: classical and modern methodological approaches]. Odarennyy rebenok, 2, 16-38. [in Russian]. 


\title{
GOAL-SETTING AMONG UNIVERSITY STUDENTS: PSYCHOLOGICAL AND
} PEDAGOGICAL BASIS OF STUDYING

Olga Ivanyuta

Candidate of Psychological Sciences, Associate Professor, Associate Professor of Psychology Department, Academician Stepan Demyanchuk International University of Economics and Humanities https://orcid.org/0000-0002-3316-9879

\begin{abstract}
Olena Yanytska
Candidate of Pedagogical Sciences, Associate Professor, Professor of Primary and Preschool Education Department of Academician Stepan Demyanchuk International University of Economics and Humanities https://orcid.org/0000-0003-4965-1720
\end{abstract}

DOI https://doi.org/10.35619/praprv.v1i16.213

\begin{abstract}
The attempts to generalize theoretically the scientific achievements of the topical problem of goal-setting in adolescence have been represented in the article. The problem of gradual formation of goal-setting has been highlighted: goal formation and its achievement by students. The significance, content of motives, structure of needs that recognize the peculiarities of goal-setting have been analyzed. The problem has been substantiated: goal-setting creates a certain direction in life, however, most students have low scores on the criterion of «life goals». The article covers functionally significant components, namely: motives, goals, actions; the research on motivation of students' goal-setting when selfish motives prevail, and social, cognitive researching are secondary, and also, research of gender features of goal-setting of students' youth have been analyzed.

The article emphasizes that the mechanism of goal-setting is not limited to motives. It includes the scope of needs, on the basis of which goals arise. The structure of needs is described: their state at the moment, the desired state, experiencing the differences between them and trying to achieve the desired. Thus, the goal retains all the components of need. It has been proved that the study of goal-setting is an analysis of the goal in the consumer-motivational sphere.

Based on the analysis of primary sources, it has been shown that goals together with motives give the activity a personal character, so it is important to draw up a plan for achieving the goal in the process of activity.

The role of abilities in goal-setting has been analyzed. It is the abilities (primarily referring to studying and work) contribute to the successful implementation of the planned activities. Based on the analysis of research, the statement has been substantiated that goal-setting is not only an activity, but also, abilities that can be developed under certain conditions. (Popova, Dmitrieva). The analysis of psychological and pedagogical aspects of goal-setting research can be the basis for the selection of goal-setting research methods for students.
\end{abstract}

Key words: goal-setting, motives, needs, activity, abilities. 